\section{DIGITAL COMMONS \\ @ UNIVERSITY OF SOUTH FLORIDA}

\section{ABO: Interactive Journal for Women in the Arts, 1640-1830}

Volume 6

Issue 2 Volume 6.2 (Fall 2016)

Article 4

2016

\title{
Review of JoEllen DeLucia, A Feminine Enlightenment: British Women Writers and the Philosophy of Progress
}

Nicole Pohl

Oxford Brookes University, npohl@brookes.ac.uk

Follow this and additional works at: https://digitalcommons.usf.edu/abo

Part of the Dramatic Literature, Criticism and Theory Commons, Educational Methods Commons, Feminist, Gender, and Sexuality Studies Commons, and the Literature in English, British Isles Commons

\section{Recommended Citation}

Pohl, Nicole (2016) "Review of JoEllen DeLucia, A Feminine Enlightenment: British Women Writers and the Philosophy of Progress," ABO: Interactive Journal for Women in the Arts, 1640-1830: Vol.6: Iss.2, Article 4. http://dx.doi.org/10.5038/2157-7129.6.2.4

Available at: https://digitalcommons.usf.edu/abo/vol6/iss2/4

This Reviews is brought to you for free and open access by Digital Commons @ University of South Florida. It has been accepted for inclusion in ABO: Interactive Journal for Women in the Arts, 1640-1830 by an authorized administrator of Digital Commons @ University of South Florida. For more information, please contact digitalcommons@usf.edu. 
Review of JoEllen DeLucia, A Feminine Enlightenment: British Women Writers and the Philosophy of Progress

\author{
Abstract \\ Review of JoEllen DeLucia's A Feminine Enlightenment: British Women Writers and the Philosophy of \\ Progress, 1759-1820. \\ Keywords \\ review, Enlightenment, Britain, progress, philosophy \\ Creative Commons License \\ (c) $($ ) $\odot$
}

This work is licensed under a Creative Commons Attribution-No Derivative Works 3.0 License. 
JoEllen DeLucia, A Feminine Enlightenment: British Women Writers and the Philosophy of Progress, 1759-1820. Edinburgh: Edinburgh UP, 2015. Edinburgh Critical Studies in Romanticism. 208pp. ISBN: 9780748695942.

Reviewed by Nicole Pohl

Oxford Brookes University

"With the History of Man, I dare say your Lordship has (con amore) written the History of Woman." [Elizabeth Montagu to Lord Kames, 27 October 1773]

JoEllen DeLucia's A Feminine Enlightenment: British Women Writers and the Philosophy of Progress, 1759-1820 lucidly explores how literary women from the Bluestockings to Ann Radcliffe, Regina Maria Roche and Maria Edgeworth tap into the contemporary debate about (historical) progress, civilization, and modernity. Using the debate over the authenticity of the Ossian poems and particularly women writers' reaction to it, DeLucia develops and complicates further Friedrich Engels's "comparative method" to explore and confront the idea of economic progress moulded by "femininity, delicacy, and refinement" (15).

DeLucia clearly documents that women writers actively debated the Scottish Enlightenment discourse of history. Indeed, DeLucia's careful and informed reading of the reception of the Ossian poems underpins current scholarly work that has challenged the hegemonic and gendered civilatory progress sketched out by Enlightenment writers and philosophers: "Ossian invites an ironic critique of the process of making history, a historiography that highlights gaps, blind spots, and the fragility of origins" (192).

DeLucia starts her fascinating study with the contention that neither Adam Smith, David Hume nor Lord Kames were clear-cut in their establishment of a conjectural history that gendered historical progress - that is, that feminine values and refinement of manners balance social and economic progress on the path to modernity. The author effectively reads Adam Smith 'against' Ossian and thus underscores her main argument. Certainly Smith (and indeed John Millar) were much more ambivalent about the gendering of virtues and were able to detect ostensibly masculine virtues of military courage and civic spirit alongside grace and emotional refinement in pre-modern societies. This reading opens up an exploration of how women writers react to the Ossian poems themselves to interject their own ideas about progress and modernity. DeLucia's argument prevails that "the women in the Ossian poems who both weep and wield a bow" provided a splendid foil on which Catherine Talbot and Anna Seward, Maria Edgeworth and Regina Maria Roche could project their own valid "stadial" fictions (153-186). This splendid opportunity would also explain why women writers of the period remained undisturbed by the inauthenticity of the Ossian poems. Ultimately, they “embraced Ossian's inauthenticity and hybridity and used him to craft associations that unsettled standard national, political, and familial frameworks" (191).

It was not only in literary writing but also in literary correspondences and salon meetings where these debates were yielded. By bringing in the Bluestocking salon meetings, DeLucia confirms that the literary networks of the time shaped and influenced political and philosophical debates that emerged in semi-private correspondences (such as between Elizabeth Montagu and Lord Kames) and literary writing (by Talbot, Elizabeth Carter or Seward). Salon culture fostered valuable literary and cultural criticism that must not be overlooked in any study on Enlightenment. So, "the Ossian poems provided a template for Bluestocking salons, where both sexes debated issues of literary, social, and political interest" (51). DeLucia shows how the Bluestockings actively engaged in fashioning the image of the modern learned woman in the light of Ossianic gatherings: 'Ossian's heroines sang alongside male bards and feasted afterwards with their male companions, all the while softening the 
manners of the opposite sex and inspiring a compassion and polish absent from other early societies, particularly the ancient civilizations of Greece and Rome" (51). Montagu went so far as to host fantastic Ossianic dinner parties, so called "feasts of shells" at which guests would drink form a "nautilus shell to the immortal memory of Ossian" (59).

Catherine Talbot's experimental imitations of Ossian and Anna Seward's 'queer' reading of the Ladies of Llangollen underscored the decentering of British literature in the period to the Caledonian margins. Equally, Ann Radcliffe gestured to the Celtic fringe in her Gothic fiction by peppering her writings with Ossianic epigraphs. If Gothic fiction and the Gothic revival challenged a more hegemonic idea about the Enlightenment, it also fed into a Whiggish and patriotic critique of imperialism that measured "the decline of the British state and anticipate a revival of the native customs of Britain" (126). The book closes with the introduction of the "stadial" fiction by Romantic-era writers such as Regina Maria Roche and Maria Edgeworth, both Irish writers who tapped into a Celtic sensibility that resisted the alignment of "commercial development with the elevation of the feminine and the refinement of sensibility" (180).

A Feminine Enlightenment: British Women Writers and the Philosophy of Progress, 17591820 is a thought-provoking book. It is based on careful close readings of literary texts and debates, and reintroduces very successfully the importance of the cultural influence of Ossian (beyond the question of authenticity) to celebrate women's distinct contribution to Scottish Enlightenment debates. As such, the book indicates possible new directions for feminist scholarship on women's writing, Scottish Enlightenment and the importance of literary networks and salons. It particularly excels in the exploration of women writers' responses to the Ossian poems and their possibilities. Ossian's poems thus function as a foil against which discourses on progress and civilisation can be explored. But one should not forget that whilst the Scottish Enlightenment constructed conjectural histories of progress (and regress), Ossian was equally based on a (Romantic) conjectural history of the Celtic fringes. As such, they indicate the tension between, as Moore has pointed out, cultural wish fulfilment and a literary critique of the Enlightenment. ${ }^{i}$ Another point should be made about the use of the term 'Bluestocking feminism.' A more complex understanding of 'Bluestocking Feminism' and a clear distinction between first and second generations of Bluestockings would have aided the overall argument. These minor quibbles aside, this is an enlightening and perceptive book.

\footnotetext{
${ }^{\text {i }}$ Dafydd Moore, "Adam Ferguson, The Poems of Ossian and the Imaginative Life of the Scottish Enlightenment.” History of European Ideas 31.2 (2005): 277-288.
} 